\title{
Phytochemical Screening by FTIR Spectroscopic Analysis and Antibacterial Activity of Sesbania grandiflora Fraction Against Edwardsiella tarda
}

\author{
Suryaningsih Ndahawali ${ }^{1 *}$, Sri Andayani ${ }^{2}$, Hardoko $^{2}$ \\ ${ }^{1}$ Master Program of Aquaculture, Faculty of Fisheries and Marine Science, Brawijaya University, Malang, Indonesia* \\ ${ }^{2}$ Department of Aquaculture, Faculty of Fisheries and Marine Science, University of Brawijaya, Malang, Indonesia
}

\section{Abstract}

Sesbania grandiflora is a medicinal plant that has been used by many Indonesian people. They have the ability as antibacterial because they contain bioactive compounds that inhibit bacterial growth. Sesbania grandiflora also contains other active compounds such as tannins, saponins, steroids, flavonoids, and terpenoids. This study aims to determine the antibacterial activity of extracts, $\mathrm{n}$-hexane fraction, ethyl acetate fraction and water fraction of Sesbania grandiflora against Edwardsiella tarda using the well diffusion method in different concentration (75 ppm, $150 \mathrm{ppm}$ dan $225 \mathrm{ppm}$ ), and knowing the active compounds of FTIR absorption bands. MIC (minimum inhibitory concentration) value of extract, $n$-hexane, ethyl acetate, and water fractions respectively was $0.51 \%, 1.11 \%, 0.97 \%$, dan $0.79 \%$. inhibitory zone diameter of the $\mathrm{n}$-hexane fraction is most active against Edwardsiella tarda bacteria. The results of FTIR identification showed that $\mathrm{n}$-hexane fraction contained flavonoids and terpenoids, as seen from absorption bands that function as antibacterial compounds.

Keywords: antibacterial, Edwardsiella tarda, FTIR, Phytochemical Sesbania grandiflora.

\section{INTRODUCTION}

Increasing aquaculture production programs carried out during the period 2010-2014 has shown tangible results with an average increase of $23.8 \%$ per year. In 2010 aquaculture production was 6.27 million tons. Whereas in 2014, it rose to reach 14.52 million tons. The value of temporary production in 2014 was Rp. 109.78 trillion [1,2]. However, aquaculture development still faced with several global challenges and problems. One of the problems in aquaculture development is the development of fish and environmental health systems, where the disease is the main obstacle [3].

The fish disease is anything that can cause interference with fish, both directly and indirectly. Many factors determine which fish become sick. The main factor is the host, pathogens (microbes, parasites), and the environment that involves physical, chemical, or behaviors such as stress [4]. Where in aquaculture is inseparable from bacterial pathogenic infections that cause the death of fish at this time. One of the infectious diseases was caused by the bacterium Edwardsiella tarda, which causes Edwardsiellosis or Emphisemathous Putreactive Disease of Catfish (EPDC).

\footnotetext{
*Correspondence address:

Suryaningsih Ndahawali

Email : srngsih@gmail.com

Address : Jl. Veteran Malang No.16, Ketawanggede, Lowokwaru, Malang, East Java 65145
}

Edwardsiella tarda is a gram-negative bacteria belonging to the cocci-shaped Edwardsiella genus with a size (0.3-1.2) $\times(1.0-0.3) \mu \mathrm{m}, E$. tarda is an Edwardsiella causative agent [5], which can cause death in fish, both freshwater and seawater habitats. These bacteria can attack fish when fish experience stress, which is caused by high stocking density, poor water quality conditions, and high organic matter content [6]. Thus, E. tarda can cause a decrease in the productivity of fish farmers, which can also cause harm to farmers. Edwardsiellosis or Emphisemathous Putreactive Disease of Catfish (EPDC) caused by E. tarda is a disease that has been known as a major disease in catfish cultivation in America. $E$. tarda infections in various types of fish that live in free waters have been reported, such as channel catfish, eels, mullet, Chinook salmon, flounder, carp, tilapia, and striped bass [7].

Cultivators generally prevent fish diseases by giving various antibiotics, such as ampicillin, tetracycline, and disinfectants. The continuous use of antibiotics if the application is not right can cause pathogenic bacteria to become resistant. There is a buildup of drug residues in the body of the fish and the aquatic environment, which in turn can endanger the consumers of aquaculture products [7]. This study aimed to determine the antibacterial activity of extracts, n-hexane fraction, ethyl acetate fraction, and water fraction of Sesbania grandiflora against Edwardsiella tarda, and 
knowing the active compounds of FTIR absorption bands.

\section{MATERIAL AND METHOD Leaves Preparation}

The leaves of Sesbania grandiflora obtained from the Sumba area, East Nusa Tenggara. The leaves of $S$. grandiflora used are old leaves, washed using heated water, drained, and airdried. The dried leaves are then blended and sifted using a sieve to obtain the desired turi leaf powder.

\section{Extraction}

Extraction process using the method of maceration with Ethanol solvent $(3: 1 \mathrm{w} / \mathrm{v})$. This process carried out for 48 hours. The longer the extraction time, the more extracted extract obtained.

\section{Fractionation}

Ethanol extract obtained from maceration in the form of a paste, dissolved in $75 \mathrm{~mL}$ of distilled water, then separated in a separating funnel with n-hexane $75 \mathrm{ml}$ added partitioned three times, then separated into $n$-hexane fraction. The residue from $n$-hexane fractionation separated from the separated species by adding ethyl acetate solvents and partitioned as much as three times. Fractionation results concentrated using a rotary evaporator, so that the $n$-hexane fraction, ethyl acetate fraction, and water fraction obtained. The extract used to inhibit or kill the growth of $E$. tarda bacteria in several concentrations, namely 75 ppm, 150 ppm, and 225 ppm.

\section{Antibacterial activity test}

Edwardsiella tarda bacterial suspension originates from the Central Java Jepara Quarantine Hall. Determination of the antibacterial activity of E. tarda was conducted by using the well method (by means of the media using a well). Then each hole filled with extracts and a fraction of 25 microlites with a dose concentration of $75 \mathrm{ppm}, 150 \mathrm{ppm}$, and 225 ppm, which diluted in $10 \%$ Dimethyl sulfoxide (DMSO).

Determination of MIC (Minimum Inhibitory Concentration) and MBC (Minimum Bactericidal Concentration) used published methods by Mohanty and Sahoo [8] by using data from testing antibacterial activity at several concentrations of $S$. grandiflora. Determination of the MIC value is done through Ln Mo ( $\mathrm{Ln}$ concentration of $S$. grandiflora leaves) on the $X$ axis against the square of the inhibiting Zone $\left(Z^{2}\right)$ on the Y-axis. The intersection between the equations obtained from linear regression $Y=a+$ $\mathrm{bX}$ with the $\mathrm{X}$-axis is the $\mathrm{Mt}$ value of $S$. grandiflora leaf fraction concentrates at $Y=0$ ). The Mt value is the MBC value, while the MIC value is $0.25 \mathrm{X} \mathrm{Mt}$.

\section{RESULT AND DISCUSSION}

Antibacterial activity

Testing the antibacterial activity of extracts, n-hexane fraction, ethyl acetate, and water at several concentrations aims to know the inhibitory concentration of the inhibitory power and the potential of $S$. grandiflora leaves as a natural antibacterial source. The results of testing the antibacterial activity showed that the extract, n-hexane fraction, ethyl acetate, and water had antibacterial activity against E. tarda bacteria indicated by the presence or absence of inhibitory zones. The results of the antibacterial activity of extracts and fractions of Turi leaves ( $S$. grandiflora) against $E$. tarda bacteria (Fig. 1)

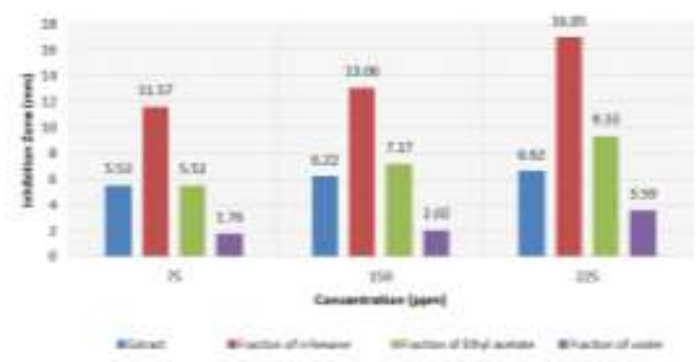

Figure 1. Antimicrobial Activity of Turi Leaves (S. grandiflora)

The results showed that the concentration of n-hexane fraction was better in inhibiting the growth of E. tarda compared to ethanol extract, ethyl acetate fraction, and water fraction, with a large inhibition zone of $16.95 \mathrm{~mm}$ at a concentration of $225 \mathrm{ppm}$. The inhibition zone was not much different from the following two concentrations of $13.56 \mathrm{~mm}$ and $11.57 \mathrm{~mm}$. It is probably due to the content of the active compound of Turi leaves, which inhibits bacterial growth and can even kill bacterial cells and the nhexane fraction containing the compounds contained therein may be an alkaloid, which has antibacterial activity [9].

The well method test showed that the largest inhibition zone was the $\mathrm{n}$-hexane fraction, which could produce a $14.32 \mathrm{~mm}$ inhibition zone of $E$. tarda with a concentration of 125 ppm, where higher concentration showed more significant inhibition zone (Fig. 1). The ability of Turi leaves to inhibit the growth of bacterial species has been reported. Turi leaves can inhibit the growth 
of Escherichia coli, Bacillus susbtilus, Staphylococcus aureus [10].

The antibacterial inhibition of Turi leaves is caused by antibacterial compounds [10]. Turi leaves are plants that have been used as medicine because they contain active ingredients such as flavonoids, alkaloids, saponins, tannins, steroids, and terpenoids [11].

Minimum Inhibitory Concentration (MIC) and Minimum Bactericidal Concentration (MBC)

MIC and $M B C$ are the minimum concentrations to kill the growth of microorganisms. The results of the concentration of the minimum inhibitor extract, the n-hexane, ethyl acetate, and water fraction against the growth of E. tarda bacteria showed in Table 1.

Table 1. Growth of E. tarda bacteria during the research

\begin{tabular}{lcc}
\hline \multicolumn{1}{c}{ Fraction } & MIC (\%) & MBC (\%) \\
\hline Extract & 0.51 & 2.02 \\
n-hexane fraction & 1.11 & 4.43 \\
Etil acetate fraction & 0.97 & 3.87 \\
Water Fraction & 0.79 & 3.16 \\
\hline
\end{tabular}

Based on the results of the wells dilution test, the MIC value of the $n$-hexane fraction is $1.11 \%$. It is indicates that the $n$-hexane fraction can inhibit the growth of E.tarda. While the MIC value of the extract, ethyl acetate, and water fractions can inhibit $E$. tarda growth, but the inhibitory zone value is small. The MBC value also showed the highest value was the $n$-hexane fraction and followed by the ethyl acetate, water, and extract fractions for $4.43 \%, 3.87 \%, 3.16 \%$, and $2.02 \%$, respectively. It shows that the content of S. grandiflora leaves, which is purified by the active compounds contained, can inhibit and kill E. tarda growth. It was explained that the compounds in non-polar and semi-polar fractions could attract polar compounds, such as flavonoids, alkaloids, and terpenoids, that can reduce bacterial growth [12].

\section{FTIR Analysis}

FTIR spectroscopy is a tool used to identify compounds, precisely organic compounds, both qualitatively and quantitatively. The analysis carried out by looking at the shape of the spectrum by looking at specific peaks that show the functional groups possessed of the compound [13]. The results of FT-n-hexane fraction analysis can be seen in Figure 2 .

The results of the FTIR spectra of Sesbania grandiflora $\mathrm{n}$-hexane fraction (Table 2) showed a range of $\mathrm{O}-\mathrm{H}$ form intermolecular hydrogen bonds with small intentions at wave number $3504.104 \mathrm{~cm}^{-1}$ which assumed to be a phenol compound. Uptake that appeared on 2940 - 2850 with wavenumber $2924.387 \mathrm{~cm}^{-1}$ is absorption from $\mathrm{CH}$ aliphatic. Absorption at $1450,696 \mathrm{~cm}^{-1}$ is a $\mathrm{C}=\mathrm{C}$ aromatic double bond belong to the flavonoid compound. Absorption band in absorption area 1490 - 1400 is a functional group $\mathrm{OH} \mathrm{RCO2H}$, which is an alcohol group. So, it assumed that in the $\mathrm{n}$-hexane fraction, it contains terpenoids. Flavonoid compounds were shown in functional groups, namely aliphatic $\mathrm{C}-\mathrm{H}$ groups and $C=C$ aromatic double bonds [14]. Terpenoid compounds are compounds that have alcohol functional groups, carboxylic acids [15].

The results of the antibacterial activity test showed $n$-hexane fraction as the most active fraction, which had the largest inhibition zone, compared to the extract, ethyl acetate, and water fraction. Terpenoid compounds, flavonoids are organic compounds that very beneficial for health, namely as an anti-inflammatory, antibacterial, antioxidant, and even as an ingredient to increase endurance. Flavonoid terpenes found in herbal plants can damage bacterial membranes by destroying the outer membrane of Gram-negative bacteria [16-18].

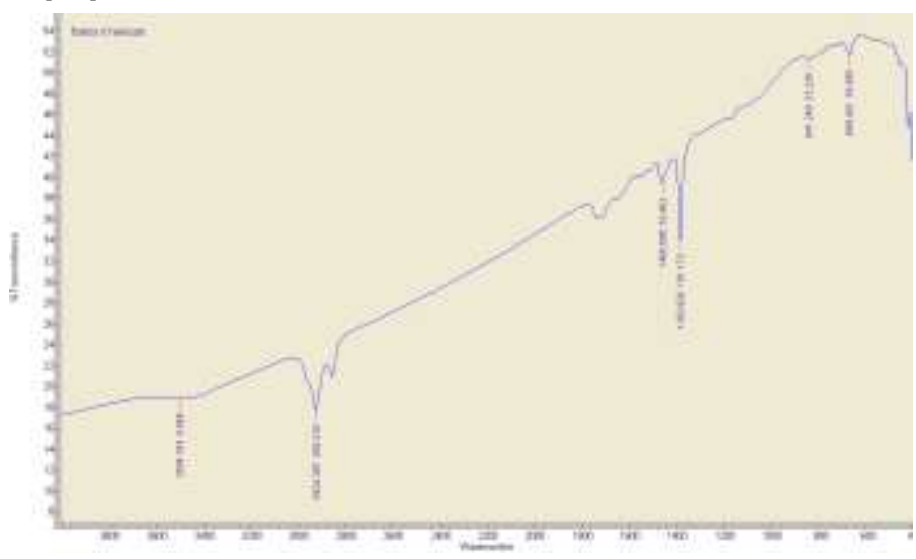

Figure 2. Analysis of $\mathrm{n}$-hexane fraction Sesbania grandiflora 

Sesbania grandiflora (Ndahawali et al)

Table 2. Isolate and Cluster absorption band numbers in the $n$-hexane fraction

\begin{tabular}{cccc}
\hline $\begin{array}{c}\text { Absorption and } \\
\text { Compound Ribbon } \\
\text { Numbers }\end{array}$ & $\begin{array}{c}\text { Absorption Ribbon } \\
\text { Numbers }\left(\mathbf{c m}^{-1}\right)[\mathbf{3 , 1 9}]\end{array}$ & $\begin{array}{c}\text { Chemical } \\
\text { Structure }\end{array}$ & Chemical Name \\
\hline $3550-3230$ & 3504.104 & $\mathrm{OH}$ & Alkane \\
\hline $2940-2850$ & 2924.387 & $\mathrm{C}-\mathrm{H}$ aliphatic & Source \\
\hline $1650-1460$ & 1450.696 & $\mathrm{C}=\mathrm{C}$ aromatic & O-H \\
$1490-1400$ & 1383.101 & $\mathrm{RCO}_{2} \mathrm{H}$ & Alcohol (H-bounded) \\
carboxylic acid
\end{tabular}

\section{CONCLUSIONS}

The results showed that $S$. grandiflora extract activity of $n$-hexane fraction, ethyl acetate fraction, and water fraction using wells diffusion method was 75 ppm, 150 ppm, and 225 ppm, as well as knowing the active compounds of FTIR absorption bands. MIC (Minimum inhibitory concentration) extract, n-hexane, ethyl acetate, and water fractions respectively $0.51 \%, 1.11 \%$, $0.97 \%$, and $0.79 \%$. Inhibition zone diameter of $n-$ hexane fraction is the most active against $E$. tarda bacteria. The identification of FTIR showed that the $n$-hexane fraction contained flavonoids and terpenoids, as seen from the absorption bands formed.

\section{REFERENCES}

[1] FAO-Food and Agriculture Organization of the United Nations, Fisheries and Aquaculture Department, The State of World Fisheries and Aquaculture. 2012. Food and Agriculture Organization of the United Nations. Eurospan (distributor). Roma and London.

[2] Abd Gafur, M., I. Isa, N. Bialangi. 2010. Isolasi dan identifikasi senyawa flavonoid dari daun Jamblang (Syzygius cumini). Research Report. Deaprtment of Chemistry. University of Gorontalo.

[3] Harborne, J.B. 2006. Metode fitokimia. penuntun cara modern menganalisis tumbuhan. Padmawinata, K. (Transl). Bandung Institute of Technology (ITB) Publisher. Bandung.

[4] Husna, N. 2015. Pengaruh pemberian serbuk daun Sambiloto (Adrographis paniculata) untuk pengobatan infeksi Edwardsiella tarda pada benih ikan mas (Cyprinus carpio). Bachelor Thesis. Study Program of Aquaculture. Malikussaleh University. North Aceh.

[5] Hasyim, M., M.A.A. Galil. 2012. Studies on Edwardsiellosis in Clarias gariepinus fish at Sohag Governorate. J. Am. Sci. 8. 438-444.

[6] Kurniawan, A. 2015. Penyakit akuatik. University of Bangka Belitung (UBB) Pres.
University of Bangka Belitung. Bangka Belitung.

[7] Jawetz, E., J.L. Melnick, E.A. Adelberg. 2012. Mikrobiologi kedokteran, $15^{\text {th }}$ Ed. Buku Kedokteran EGC. Jakarta. 230-231.

[8] Mohanty, B.R., P.K. Sahoo 2007. Edwardsiellosis in fish: a brief review. J. Biosci. 32. 1331-1344.

[9] Mogi, B., R. Harjanti, R.A. Samsumaharto. 2016. Uji aktivitas antibakteri ekstrak etanol, fraksi $n$-heksana, etil asetat, dan air dari daun Turi (Sesbania grandiflora Pers) terhadap bakteri Shigella dysenteriae ATCC 9361. Biomedika. 9(2). 30-35.

[10] Padmalochana, K., D.M.S. Rajan. 2014. Antimicrobial activity of aqueous, ethanol and acetone extracts of Sesbania grandiflora leaves and its phytochemical characterization. Int. J. Pharma Sci. Res. 5. 957-962.

[11] Rahayu, M., S. Sunarti, D. Sulistiarini, S. Prawiroatmodjo. 2006. Pemanfaatan tumbuhan obat secara tradisional oleh masyarakat lokal di pulau Wawonii, Sulawesi Tenggara. Biodiversitas. 7. 245250.

[12] Makkawi, A.J.J., E.M. Keshk, M.M. ElShamy, M. Abdel-Mogib. 2015. Phytochemical and biological evaluation of Ambrosia maritima. Res. J. Pharm. Biol. Chem. Sci. 6(4). 16781688.

[13] Ragasa, C.Y., P. Tsai, C. Shen. 2009. Antimicrobial terpenoids from Erigeron sumatrensis. NRCP Res. J. 10(1). 27-32.

[14] Vipin, K., G.K. Arun, G. Rajesh. 2011. Antimicrobial activity of Sesbania grandiflora (L.) Pers. Int. Res. J. Pharm. 2. 85-87.

[15] Lewis, K., F.M. Ausubel. 2006. Prospects of plant derived antibacterials. J. Nat. Biotech. 24. 1504-1507.

[16] Bonjar, S. 2004. Evaluation of antibacterial properties of some medicinal plants used in Iran. J. Ethnopharmacol. 94. 301-305. 
[17] De Boer, H.J., A. Kool, A. Broberg, W.R. Mziray. 2005. Antifungal and antibacterial activity of some herbal remedies from Tanzania. J. Ethnopharmacol. 96. 461-469.

[18] Islam, B., S.N. Khan, I. Haque, M. Alam, M. Mushfiq, A.U. Khan. 2008. Novel antiadherence activity of mulberry leaves: inhibition of Streptococcus mutans biofilm by 1-deoxynojirimycin isolated from Morus alba. J. Antimicrob. Chemother. 62. 751-757.

[19] Silverstein, R.M., F.X. Webster, D.J. Kiemle. 2005. Spectrometric identification of organic compounds, $7^{\text {th }}$ Ed. John Wiley and Sons. USA.

[20] Chemistry Libretexts. 2018. Organic Chemistry. Available at: https://chem. libretexts.org/Bookshelves/Organic_Chemis try. 